\title{
Thousand Copies per Milliliter
}

National Cancer Institute

\section{Source}

National Cancer Institute. Thousand Copies per Milliliter. NCI Thesaurus. Code C100897.

The unit of concentration expressed as the number of 10 to the third power copies in unit volume equal to one milliliter. 